\title{
"My Parents Do not Care": Analysis of Parental Treatment of Lesbians
}

\author{
Asmidir Ilyas ${ }^{1}$, Afdal Afdal $^{2 *}$, Ifdil Ifdil ${ }^{3}$, Zadrian Ardi ${ }^{4}$, Miftahul Fikri $^{5}$ \\ 12345 Guidance and Counseling, Faculty of Education,Universitas Negeri Padang, Indonesia
}

\begin{abstract}
Lesbian behavioral trends occur due to lack of control of parents who are not concerned with the activities of their children, causing children to do things that deviate from the prevailing values and norms. The purpose of this study to determine the condition of family background as the cause of lesbian in Padang. This research uses Qualitative method with case study design. The subjects of this study were three lesbians. Data were obtained by using participant observation technique and in-depth interview. The results showed factors causing lesbian behavior in the study subjects because of family background conditions that are less harmonious. With regard to the need for implications for parental parenting to prevent lesbian behavior is discussed further.
\end{abstract}

Keywords

Lesbian behavior; Family conditions; Parental treatment

Article Received: 20 September 2020, Revised: 30 November 2020, Accepted: 18 December 2020

\section{Introduction}

Lately, lesbian has become an interesting conversation because of social deviations which certainly have a negative impact on the nation's successors in Indonesia. Lesbian is one of the phenomena of homosexuality which is currently growing more and more even though it is veiled. Lesbians rarely appear in public, but lesbian development is quite rapid through cyberspace or small lesbian communities. This is evidenced by the number of lesbian communities in cyberspace, such as sepocikopi, satu pelangi, and other lesbian groups on countless social networks. Lesbian phenomena are no longer carried out in private but have dared to publish that they are lovers or dating by showing intimate photos (photos bribing food, hugs and kisses) on social media such as Instagram and Facebook with his girlfriend (same sex). Lesbian use the community to make fellow lesbian parties and to gather together.

There is even a big party that is held every few years by a large community to gather lesbians from small communities. Aleardo

(Zanghellini, 2007) revealed that a person who carries out lesbian behaviour tends to cover their identity from society, but sometimes lesbians lose control of themselves and they want to be recognized in public. Some studies show factors that cause lesbian behavior. The tendency of lesbian behavior is influenced by the formation of personality which includes biological factors such as genetics, disharmony in the family and a wrong social environment (Setiadi \& Kolip, 2012). Furthermore, the influence of family conditions, poor sexual experience in childhood play a role in the cause of lesbian behavior One of the factors that causes lesbian behavior is family background conditions that are not harmonious (Setiadi \& Kolip, 2012). Factors that influence someone to become lesbian are the existence of pure feelings from themselves due to being hurt by their lover or traumatized by men, because of poor family influence, and also influenced by the environment and wrong friends so that they join in trying to be lesbian (Sari \& Bahri, 2017). he purpose of this study is to test the theory of the background conditions of families that are not harmonious as a cause of lesbian behavior (Tarigan, 2012) city of Padang.

\section{Method}

This study uses a qualitative method. Data were collected using the technique of participant observation and in-depth interviews. Subject determination was done with Snow ball sampling so that it could be identified in depth about the causes of lesbian behavior. The subjects in this study were 3 lesbian people who lived in the city of Padang. The research design used is a case 
study, in which research is carried out intensively, in detail and deeply on the object of research to answer the problems of the researcher.

Data analysis consists of three lines of activities that occur simultaneously, namely: data reduction, data presentation, conclusion drawing / verification (Miles \& Huberman, 1992) stated in the picture below.

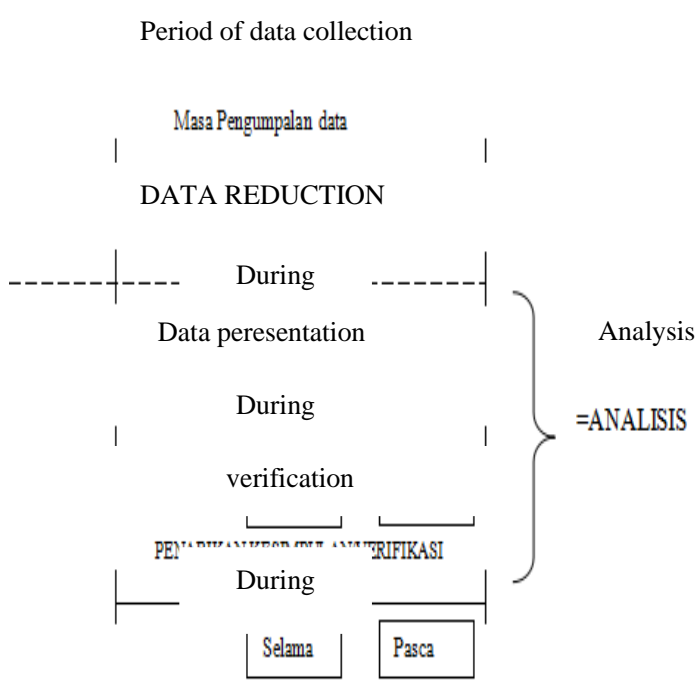

\section{Results and Discussion}

Based on the results of observations and interviews, information was obtained that the causes of lesbian behavior in each research subject:

\section{Subject 1 (name initial M)}

Based on the results of observations and interviews, it was found that the $\mathrm{M}$ comes from a broken home family, where M's father remarried without his mother's knowledge, and currently M's mother had been jailed for some bad actions. M lived with his father, stepmother and a stepbrother. $\mathrm{M}$ had been invited by her brother to play with boys since childhood.

The beginning of $\mathrm{M}$ entered the lesbian group when the junior high school, she skipped to the many gathering cafe butchy (a masculine figure with a manlike appearance and acting as a man in a relationship), in the cafe the subject received attention and the comfort of her friends. Then the subject was invited to date a butchy, initially just trying to establish a relationship with Butchy, but the longer felt comfortable and liked to have relationships with girl.

The causes of deviant behavior according to (Setiadi \& Kolip, 2012) are due to environmental influences (one of which is a less harmonious family environment) and the mass media. Factors that cause adolescent deviance are family environment factors, school environment factors, community environmental factors, television (as one of the media that can cause deviant behavior), and the social environment or friendship both at school and outside school is one of the supporting factors for the occurrence of deviant behavior of adolescents. Poor peer conditions make it necessary for someone to follow things that are not good or behave deviant as well (Jonaidi \& Nurmanina, 2013; Simons \& Burt, 2011). In this study, it can be seen that $\mathrm{M}$ is in an environmental influence where she associates with friends who ultimately influence her to become a lesbian. Furthermore (Setiadi \& Kolip, 2012) states that social heritage is more influenced by the wrong form of socialization.

In line with that, Erna \& Sari (Sari \& Bahri, 2017) mentioned that the factors that influence a person to become lesbian are one of them is due to poor family influence, and also influenced by the environment and and peer environmental factors. (Jonaidi \& Nurmanina, 2013) A person's behavior can influence one another. If a friend associates someone often does things that deviate from the rules then a person's behavior is likely to be affected or following the behavior of his/her friend. An unhealthy environment, such as an environment with many members of the community who deviate will greatly influence the formation of children's behavior (Bremer, 2014; Jingzhong \& Lu, 2011), therefore parents must pay attention to the right environment for their child's growth.

\section{Subject 2 (name initial F)}

Based on the results of observations and interviews, obtained information from the subject regarding family conditions. the subject's father was a soldier and his mother was a school principal. Both parents are busy with their work so the subject can rarely be with both parents and $\mathrm{F}$ 
is not getting enough attention of her family. But the causes of family background conditions are supported by other factors, the cause of subject being a lesbian and being a femme (feminine figure with a woman's appearance and acting as a woman in a relationship) because of the influence of friendship environment, where initially the subject was targeted by victims lesbians to be made into femme in relationships. But in reality the subject is now falling into the world of lesbians, because she feel comfortable dating with same-sex (Bachmann, 2011; Jennings, Mellish, Tasker, Lamb, \& Golombok, 2014).

The assumption that lesbians are seen as one of deviant behavior, which can be sourced from outside the individual concerned such as the family environment, as explained by Mudjiran dkk (Mudjiran, 1999) one of which is because low parental control causes a lack of discipline in family life. Some of the causes of LGBT are family negligence, relationships and environment, morals and morals and weak religious knowledge (Barbarin \& Richter, 2013; Musti'ah, 2016).

Furthermore (Sari \& Bahri, 2017) the factors that influence someone to be lesbian are the existence of pure feelings from themselves due to being hurt by their lover or traumatized by men, because of poor family influence, and also influenced by the environment and friends. Some Femme informants become lesbian due to invitations from friends, while Bucthy is usually supported by physical factors as well as their character, where they have been formed into tomboyish girls and have deviant sexual orientations or different sex orientations with heterogeneous sex orientations (Brown, 2018; Chou, 2012; Wong, 2017). When viewed from the statement, in addition to the influence of the friendship environment, the condition of the $\mathrm{F}$ family is that both parents are too busy with their work so that $\mathrm{F}$ feels less attention and her parents don't have much time for her, so F would rather go out with friends and get attention from same-sex couples and comfort in the presence of friends.

\section{Subject 3 (name initial S)}

Based on the results of observations and interviews, information obtained from the subject about the condition of the family background of $S$ who is not harmonious, always noisy and different opinions between father and mother, and his father having an affair with his co-worker. This makes $\mathrm{S}$ have a poor perception of men. $\mathrm{S}$ assume that men always perceive women as weak who can be mocked by their feelings. Furthermore, the result of an inharmonious family condition made $S$ often skip school and went to a cafe where there were many butchy, femme and andro, when the subject was arranged by a butchy named F. Initially the subject did not know that $\mathrm{F}$ was a girl, but after the relationship runs three weeks the subject knows that $\mathrm{F}$ is a girl, but the subject does not matter if her girlfriend is same-sex with her, because the $\mathrm{S}$ already feels comfortable, coupled with the thinking about men can not be trusted.

Nowadays, S has become an andro (can be both, can act as a woman in a relationship and act as a man) in a lesbian association, even $\mathrm{S}$ covers her status as a lesbian by dating men.

Parents play an important role in the child's decision making to become a lesbian. How parents treat children also influences the decision of children to become lesbians. As explained by (Setiadi \& Kolip, 2012) hat lesbians are one of the deviant behaviors caused by disharmony in the family, which arises when the family is unable to maintain their integrity so that the family concerned is broken. This is in line with Soba and Herningsih (Herningsih, Fatmawati, \& Salim, 2015; Wahyuningtyas, 2017) who states that family circumstances can be a cause of behavioral irregularities in adolescents such as broken homes, disadvantaged families, the busyness of parents that makes children lack love, wrong parenting, and the position of children in the family. Iqbal (Iqbal, 2014) revealed that deviant behavior was caused by family, school and community environments. The family can influence the growth of children because the family environment is the first environment for children to get socialization from their parents (Afdal, 2014, 2015)

Thus, it can be said that the bad behavior of children, the family is very instrumental in shaping the attitudes or behavior of children. That is, if the socialization built in the family is not 
good, the behavior of the child also becomes bad. Conversely, if the socialization built in the family is good, the child will grow well too. Hartono \& Gianawati (Hartono, 2013) revealed that families have a tremendous influence in the formation of children's character and personality. From the confession of Subject, it can be explained that he in his family lacked conducive communication with his parents since childhood.

\section{Conclusions}

From the results, it was found that poor family background conditions were one of the causes of lesbian behavior. Data obtained from the observation and interviews of all three subjects became lesbians because of poor family background conditions, lack of attention from the family became the reason for the subjects to seek attention outside the home, by gathering with friends who were butchy and finally intertwined a same-sex relationship. Conditions that justify Setiadi \& Kolip (Setiadi \& Kolip, 2013) theory of the causes of lesbian behavior are one of the family backgrounds that are not harmonious because discomfort in the family makes the subject decide to look for other comforts outside the home and peer environment also supports the causes of behavior lesbian.

\section{References}

[1] Afdal, A. (2014). Kolaboratif: Kerangka kerja konselor masa depan. Jurnal Konseling dan Pendidikan, 3(2), 1-7.

[2] Afdal, A. (2015). Pemanfaatan Konseling Keluarga Eksperensial untuk Penyelesaian Kasus Kekerasan dalam Rumah Tangga. Jurnal EDUCATIO: Jurnal Pendidikan Indonesia, 1(1).

[3] Bachmann, I. (2011). Civil partnership-"gay marriage in all but name": A corpus-driven analysis of discourses of same-sex relationships in the UK parliament. Corpora, 6(1), 77-105.

[4] Barbarin, O. A., \& Richter, L. M. (2013). Mandela's children: Growing up in postapartheid South Africa: Routledge.

[5] Bremer, A. E. (2014). Cultivating humannature relationships: The role of parents and primary caregivers in development of environmental identity.

[6] Brown, C. J. (2018). On Being Trans: Narrative, Identity, Performance, and Community.

[7] Chou, R. S. (2012). Asian American sexual politics: The construction of race, gender, and sexuality: Rowman \& Littlefield Publishers.

[8] Hartono, R. D. (2013). Faktor-faktor yang menyebabkan remaja berperilaku menyimpang.

[9] Herningsih, H., Fatmawati, F., \& Salim, I. (2015). Penyebab Terjadinya Perilaku Menyimpang "Ngelem" pada Siswa di SMPN 3 Subah Kabupaten Sambas. Tanjungpura University.

[10] Iqbal, M. (2014). Penanggulangan Perilaku Menyimpang (Studi Kasus SMA Negeri 1 Pomalaa Kab. Kolaka Sulawesi Tenggara). Lentera Pendidikan: Jurnal Ilmu Tarbiyah dan Keguruan, 17(2), 229-242.

[11] Jennings, S., Mellish, L., Tasker, F., Lamb, M., \& Golombok, S. (2014). Why adoption? Gay, lesbian, and heterosexual adoptive parents' reproductive experiences and reasons for adoption. Adoption Quarterly, 17(3), 205-226.

[12] Jingzhong, Y., \& Lu, P. (2011). Differentiated childhoods: impacts of rural labor migration on left-behind children in China. The Journal of peasant studies, 38(2), 355-377.

[13] Jonaidi, N. M., \& Nurmanina, A. (2013). Analisis Sosiologis Terhadap Perilaku Menyimpang Siswa pada SMA Pembangunan Kabupaten Malinau. 1(3), 11-24.

[14] Miles, M. B., \& Huberman, A. M. (1992). Analisis data kualitatif: Jakarta: UI press.

[15] Mudjiran, D. (1999). Perkembangan Peserta Didik. Padang: UNP Press.

[16] Musti'ah. (2016). Lesbian Gay Bisexual and Transgender (LGBT): Pandangan Islam, Faktor Penyebab, dan Solusinya. 3(2), 258273. 
[17] Sari, E. R., \& Bahri, S. (2017). Kehidupan Pasangan Lesbian (Studi Kasus di Kota Pekanbaru). Riau University.

[18] Setiadi, E. M., \& Kolip, U. (2012). Pengantar Sosiologi.(2011). Jakarta: Kencana.

[19] Setiadi, E. M., \& Kolip, U. (2013). Pengantar sosiologi politik: Kencana.

[20] Simons, R. L., \& Burt, C. H. (2011). Learning to be bad: Adverse social conditions, social schemas, and crime. Criminology, 49(2), 553-598.

[21] Tarigan, M. (2012). Komunikasi Interpersonal Kaum Lesbian di Kota Pontianak Kalimantan Barat. UPN Veteran Yogyakarta.

[22] Wahyuningtyas, S. E. (2017). Keberfungsian Keluarga Dengan Perilaku Seksual Berisiko Pada Remaja Di Kecamatan Sumbersari Kabupaten Jember.

[23] Wong, Y. Y. (2017). Learning to be a lesbian: identity and sexuality formation among young Hong Kong lesbians.

[24] Zanghellini, A. (2007). Lesbian and gay identity, the closet and laws on procreation and parenting. Griffith Law Review, 16(1), 107-130 